\title{
Position Promotion and Employee Performance in The Regional Secretariat of Makassar City
}

\author{
Muhammad Nur Yamin 1 , Herlina Sakawati ${ }^{2}$, Nur Qamaria Putri ${ }^{3}$ \\ Public Administration Science, Fakultas Ilmu Sosial, Universitas Negeri Makassar \\ Email: Nuryamin1@gmail.com
}

(Received: September 6-2019; revised: November 15-2019; published: December 31-2019)

\begin{abstract}
The research aims to find out how the influence of job promotions on employee performance in the Makassar City Regional Secretariat by using quantitative methods. Determination of the sample in the study using the slovin formula as many as 73 employees with a simple random sampling technique. Data collection techniques using observation, questionnaires and documentation. The data analysis technique used is simple linear regression and test. The results showed that: (1) The level of promotion in the Makassar City Regional Secretariat was in the good category following the operational standard procedures in accordance with Law No. 5 of 2014 and its derivative rules, (2) the level of performance of employees in the Makassar City Regional Secretariat is in the very high category, and (3) the t-test shows that $\mathrm{H} 0$ is rejected and $\mathrm{H} 1$ is accepted, which means that promotion is a positive and significant effect on employee performance in the Makassar City Regional Secretariat shown by the equation Ý $=11.614+$ 0.711X. Basically employees have the desire to experience promotions will tend to have good performance, if achieved or not the performance targets are used as a basis for assessment in the promotion of positions in addition to loyalty, education level and work experience. Leaders must pay more attention to the promotion of positions to employees who are able to maintain high performance, the promotion of the right position as needed will have a positive influence on improving employee performance.
\end{abstract}

Keywords: Job promotion; employee; performance

\section{INTRODUCTION}

Human resources (HR) is the most important part in an organization (Jerónimo et al., 2019). Human resources are needed as a driving factor for other components contained in an organization, without the role of human resources organizational activities can not be carried out properly and regularly (Saggaf et al., 2014; Salam, 2015; Shah et al., 2017). So the organization must always foster and develop the potential of its human resources as a very valuable asset.

One effort that can be done is to do a promotion program (Chitescu \& Lixandru, 2016). Hasibuan (2018) argues that promotion is a move that enlarges the authority and responsibility of employees to higher positions in an organization so that obligations, rights, status, and producers the greater the. The importance of developing human resources is done to create better employee performance than before so that the objectives of the organization can be achieved.

Efforts to improve employee performance are not easy, and therefore there is a need for employee motivation by career development, one of which is by promoting positions. This is evidenced by the previous research conducted by (Vianti \& Netra, 2013) entitled "The Effect of Leadership Style, Job Promotion and Financial Compensation on Employee Performance at PT. 
328 Jurnal Ilmiah Ilmu Administrasi Publik: Jurnal Pemikiran dan Penelitian Administrasi Publik

Volume 9 Number 2, July- December 2019. Page 326-334

Grand Mega Bali Resort \& Spa Kuta Bali "where the results of his research indicate that the promotion variable has a significant effect on employee performance.

The potential of its human resources as a very valuable asset. One effort that can be done is to do a promotion program. Hasibuan (2018: 108) argues that promotion is a move that enlarges the authority and responsibility of employees to higher positions in an organization so that obligations, rights, status, and producers the greater the. The importance of developing human resources is done to create better employee performance than before so that the objectives of the organization can be achieved (Akib \& Salam, 2016; Pratiwi et al., 2019).

Employee development through job promotion programs is intended to provide experience in carrying out management functions at a higher structural level than before, where the new position has broader and heavier responsibilities, so employees are required to work harder to improve their abilities so that their duties and responsibilities can be carried out successfully.

Job promotion programs can be implemented if there are positions that have not been filled or there are vacancies as well as the re-evaluation of old positions. The opportunity to fill a position is first given to those who have fulfilled all the requirements regarding the implementation of the promotion. Ardana in Vianti \& Netra (2013) regarding several criteria that need to be considered before conducting promotions, namely seniority, quality of education, work performance and level of loyalty. Placement of employees is done by making adjustments to the needs of the organization associated with planning to get the right people in the right position as well or commonly known as "right man on the right place". To get a good and professional, responsible, honest and fair state civil apparatus, a recruitment system based on open capability based on capability is needed (Nilwana et al., 2015; Simon et al., 2016). In theory, the application of a merit system is still not optimal and optimal to be implemented. According to Law Number 5 of 2014, the implementation of a merit system is a necessity that needs to be done by the government.

The enactment of Law No. 5 of 2014 concerning ASN is expected to have a significant impact on institutional changes, career systems and remuneration because this law overhauled a system of recruitment, fostering and career development which included a career gaps system and filling high positions through open promotion. To guarantee the selection of professional and competent people, according to job competency standards (Salam et al., 2014).

The state apparatus has the same rights and opportunities to be able to fill structural positions in government (Niswaty et al., 2016). Open promotion of this position through a number of lengthy processes, ranging from Administrative requirements such as Rank and Group, making papers, presentations, interviews to assessment. From this process, it is expected to produce the best people to occupy the positions in question. Makassar City Regional Secretariat in the management of civil servants refers to Government Regulation No. 11 of 2017 which is a derivative of Law No. 5 of 2014.

There is still an imbalance in the promotion of positions in the organization, because sometimes promotional activities are still influenced by subjectivity and kinship elements so that it ignores the conditions that have been set as the basis for conducting promotions. In addition, the phenomenon that occurs in government organizations that is sometimes the implementation of promotion is not based on the principles of professionalism and objective 
conditions set, sometimes the position given is not in accordance with the expertise and educational background.

Job promotion provides an important role for every employee, even a dream that is always waiting for. If there is an opportunity for employees to be promoted based on the principles of fairness and objectivity, employees will be motivated to work harder, be more enthusiastic, discipline, and achieve work so that organizational goals can be optimally achieved. Organizations need high-performing employees, at the same time employees need feedback on their performance as a guide for their actions in the future.

The existence of promotional targets, makes employees feel valued, cared for, needed and recognized by their organization's work ability so that they will produce high outputs and will enhance the morale of the organization. This is also evidenced by research conducted by (Eka et al., 2016) with the title "The Effect of Job Promotion and Work Discipline on Employee Performance", where the results of his research indicate that there is a positive and significant influence of the promotion variable on employee performance in the District Transportation Office Buleleng.

Organizations can help employees develop the ability or potential and achieve desired careers by organizing employee training programs that can improve employee performance so that the organization can provide a "reward" in the form of promotion. Thus it is hoped that employees and organizations can benefit each other and achieve the goals set. Based on the description above, the author is interested in conducting research under the title "Job Promotion and Employee Performance at the Makassar City Regional Secretariat"

\section{METHOD}

This research uses quantitative methods with associative research types and forms of causal relationships (Creswell \& Creswell, 2017). Associative research is research that aims to determine the relationship between two or more variables. While a causal relationship is a causal relationship. The population in this study is the entire State Civil Apparatus at the Makassar City Regional Secretariat of 267 employees. Then the sample is drawn using the Slovin formula and produces a total sample of 73 employees. Data collection techniques using observation, questionnaires and documentation. Data analysis techniques using simple linear regression analysis with the help of SPSS version 24, $t$ test and to see the percentage level of each variable, this study uses the Likert scale categorization.

\section{RESULT AND DISCUSSION}

\section{Job Promotion}

Promotion is an increase in the position of an employee from a previous position to a higher position, promotion can be in the form of a promotion from low to a higher position. To measure the promotion of positions in the Makassar City Regional Secretariat, 4 indicators used by (Thoha, 2003) were used, namely Work Professionalism, Loyalty, Education Level, and 
330 Jurnal Ilmiah Ilmu Administrasi Publik: Jurnal Pemikiran dan Penelitian Administrasi Publik Volume 9 Number 2, July- December 2019. Page 326-334

Work Experience. The percentage rate of Job Promotion for each indicator can be seen in the following table:

\section{Table 1}

Achievement Rate of Job Promotion Score

\begin{tabular}{llllll}
\hline \multicolumn{1}{c}{$\begin{array}{c}\text { Job promotion } \\
\text { indicators }\end{array}$} & $\begin{array}{c}\text { Number } \\
\text { of Items }\end{array}$ & $\begin{array}{c}\text { Score } \\
\text { achieved }\end{array}$ & $\begin{array}{c}\text { Ideal } \\
\text { Score }\end{array}$ & $\begin{array}{c}\text { Achievement } \\
(\mathbf{\%})\end{array}$ & Category \\
\hline Work Professionalism & 2 & 610 & 730 & 83,56 & Very high \\
Loyalty & 2 & 614 & 730 & 84,10 & Very high \\
Level of education & 3 & 889 & 1.095 & 81,18 & Very high \\
Work experience & 3 & 897 & 1.095 & 81,91 & Very high \\
\hline Amount & $\mathbf{1 0}$ & $\mathbf{3 . 0 1 0}$ & $\mathbf{3 . 6 5 0}$ & $\mathbf{8 2 , 4 6}$ & Very high \\
\hline
\end{tabular}

Source: Processed Data Results, Indicators 1-10

Based on table 1, it can be seen that the percentage level of achievement of the promotion variable is in the very high category with the calculation result of $82.46 \%$, the results of measuring the promotion of the position through the four indicators above shows that all indicators support to be a requirement in conducting promotion.

\section{Employee Performance}

Employee performance is the work of individuals in an organization. To measure the performance of employees in the Makassar City Regional Secretariat using 5 indicators proposed by (Mangkunegara, 2000), namely Work Quality, Work Quantity, Responsibility, Cooperation, and Initiatives. The percentage level of Employee Performance for each indicator can be seen in the following table:

Table 2

Level of Achievement of employee Performance scores

\begin{tabular}{llllll}
\hline $\begin{array}{c}\text { Job promotion } \\
\text { indicators }\end{array}$ & $\begin{array}{c}\text { Number } \\
\text { of Items }\end{array}$ & $\begin{array}{c}\text { Score } \\
\text { achieved }\end{array}$ & $\begin{array}{c}\text { Ideal } \\
\text { Score }\end{array}$ & $\begin{array}{c}\text { Achievement } \\
(\%)\end{array}$ & Category \\
\hline Work quality & 2 & 575 & 730 & 78,76 & High \\
work quantity & 2 & 582 & 730 & 79,72 & High \\
responsible & 2 & 619 & 730 & 84,79 & Very high \\
cooperation & 2 & 622 & 730 & 85,20 & Very high \\
initiative & 2 & 589 & 730 & 80,68 & High \\
\hline amount & $\mathbf{1 0}$ & $\mathbf{2 . 9 8 7}$ & $\mathbf{3 . 6 5 0}$ & $\mathbf{8 1 , 8 3}$ & Very high \\
\hline
\end{tabular}

Source: Processed Data Results, Indicators 11-20

Based on table 2, it can be seen that the percentage level of achievement of employee performance variables is in the very high category with the calculation results of $81.83 \%$, the results of measuring employee performance through the five indicators above indicate that all indicators support to improve employee performance. 


\section{Effect of Job Promotion on Employee Performance}

The results of data analysis using SPSS version 24 show that position promotion has a positive and significant effect on employee performance at the Makassar City Regional Secretariat. The results of a simple linear regression analysis assisted by SPSS version 24, can be seen as follows:

\section{Table 3.}

Simple Linear Regression Analysis

\begin{tabular}{|c|c|c|c|c|c|}
\hline \multirow{2}{*}{ Model } & \multicolumn{2}{|c|}{$\begin{array}{c}\text { Unstandardized } \\
\text { Coefficients }\end{array}$} & \multirow{2}{*}{$\begin{array}{c}\begin{array}{c}\text { Standardized } \\
\text { Coefficients }\end{array} \\
\text { Beta }\end{array}$} & \multirow[b]{2}{*}{$\mathbf{t}$} & \multirow[b]{2}{*}{ Sig. } \\
\hline & B & $\begin{array}{c}\text { Std. } \\
\text { Error }\end{array}$ & & & \\
\hline 1. $\quad$ (Constant) & 11,614 & 3,385 & & 3,431 & 0.001 \\
\hline Promotion of position & 0,711 & 0,082 & 0,718 & 8,687 & 0.001 \\
\hline
\end{tabular}

a. Devendent Variable: employee performance

Based on table 3, the linear regression results can be obtained as follows: Constant numbers (a) of 11,614 and coefficient of variables (b) Job Promotion of 0.711, a simple linear regression equation model for this study can be made as follows:

$\mathrm{Y}=\mathrm{a}+\mathrm{b} \mathrm{X}$

$\mathrm{Y}=11,614+0.711 \mathrm{X}$

$\mathrm{a}=$ constant value in research

This is 11,614 , meaning that if the Job Promotion is assumed to be zero (0) then the Employee Performance is worth 11,614. $\mathrm{b}=$ number of regression coefficients in this research amounted to 0.711 , means every improvement Job Promotion of 1 unit, it will be improve employee performance amounted to 0.711 .

\section{T test}

T-test or partial test is used to test the effect of independent variables on the dependent variable partially or individually. Technically the test is done by comparing the value of tcount with the value of $\mathrm{tt}$ able at a significance level $\mathrm{a}=0.05$.

The $\mathrm{t}$-value of the promotion variable $(\mathrm{X})$ is greater than the $\mathrm{t}$-table value $(8.697>1.666)$ and the significance value (sig.) Is smaller than required $(0,000<0.05)$. These results indicate that $\mathrm{HO}$ is rejected and $\mathrm{H} 1$ is accepted, which means promotion of a positive and significant effect on employee performance at the Makassar City Regional Secretariat.

Based on the results of these calculations it can be seen that employee performance has a positive and significant effect on the promotion of position. The results of this study are supported by the opinion of Nitisemito (2008) job promotion is the process of moving employees from one position to another position that is higher than the position previously occupied. Promotion of the right position according to needs will have a positive influence on improving employee performance. 
332 Jurnal Ilmiah Ilmu Administrasi Publik: Jurnal Pemikiran dan Penelitian Administrasi Publik Volume 9 Number 2, July- December 2019. Page 326-334

\section{CONCLUSION}

Based on the results of research on the effect of job promotion on employee performance in the Makassar City Regional Secretariat, then in this chapter several conclusions will be drawn as follows:

a. Position promotion in the Makassar City Regional Secretariat in general has been in a very high category, in the sense that Position Promotion is in accordance with the merit system contained in Law No. 11 of 2017 and is the basis for implementing promotion in the Makassar City Regional Secretariat.

b. The performance of employees in the Makassar City Regional Secretariat in general is already in the very high category, in the sense that employee performance is in line with organizational expectations. However, indicators of work quality and quantity of work are still at a lower percentage compared to other indicators.

c. Position promotion has a positive and significant effect on employee performance at the Makassar City Regional Secretariat. This can be seen from the analysis of the data obtained, namely $t$ count 8.697> t table 1.666 and Sig $0.000<0.05$. The analysis of the data shows a hypothesis which states that there is a positive and significant influence on the promotion of the employee's performance so that the hypothesis can be accepted.

\section{REFERENCES}

Akib, H., \& Salam, R. (2016). Analisis Kualitas Pelayanan Publik Berbasis Importance Performance Analysis (IPA) pada Kecamatan Kota Makassar. Jurnal Ilmiah Scientific Pinisi, 2(April 2016), 16-20.

Chitescu, R. I., \& Lixandru, M. (2016). The Influence of the Social, Political and Economic Impact on Human Resources, as a Determinant Factor of Sustainable Development. Procedia Economics and Finance, 39, 820-826. https://doi.org/https://doi.org/10.1016/S2212-5671(16)30259-3

Creswell, J. W., \& Creswell, J. D. (2017). Research design: Qualitative, quantitative, and mixed methods approaches. Sage publications.

Eka, I., Putra, G. S., Susila, G. P. A. J., \& Yulianthini, N. N. (2016). Pengaruh Produksi, Biaya Promosi, dan Biaya Distribusi terhadap Penjualan. E-journal Bisma Universitas Pendidikan Ganesha, Bali. Jurusan Manajemen.

Hasibuan, M. (2018). Analisis Pengaruh Mutasi, Promosi Jabatan dan Kepuasan Kerja Terhadap Kinerja Karyawan Pimpinan Kantor Direksi PT. Perkebunan Nusantara II.

Jerónimo, H. M., Henriques, P. L., Lacerda, T. C. de, da Silva, F. P., \& Vieira, P. R. (2019). Going green and sustainable: The influence of green HR practices on the organizational 
rationale for sustainability. Journal of Business Research. https://doi.org/https://doi.org/10.1016/j.jbusres.2019.11.036

Mangkunegara, A. A. A. P. (2000). Manajemen sumber daya manusia perusahaan. Remaja Rosdakarya.

Nilwana, A., Akib, H., Rusdi, M., \& Tahmir, S. (2015). Competency Based Analysis on Government Apparatus Performance in Sidenreng Rappang Regency South Sulawesi Province. International Journal of Academic Research, 7(1).

Niswaty, R., Darwis, M., Alimuddin, W., \& Salam, R. (2016). Pengaruh Penerapan Prinsip Good Governance terhadap Efektivitas Kerja Pegawai. Jurnal Ilmiah Administrasi Publik (JIAP), 95-100.

Nitisemito, A. (2008). Manajemen Personalia Ghalia. Indonesia. UGM, Yogyakarta.

Pratiwi, N. J., Jamaluddin, J., Niswaty, R., \& Salam, R. (2019). The Influence of Work Facilities on Employee Performance at the Regional Financial Management Agency Secretariat Section of South Sulawesi Province. Jurnal Ad'ministrare, 6(1), 35-44.

Saggaf, S., Salam, R., Kahar, F., \& Akib, H. (2014). Pelayanan Fungsi Administrasi Perkantoran Modern. Jurnal Ad'ministrare, 1(1), 20-27.

Salam, R. (2015). Penerapan Fungsi Administrasi Perkantoran Modern berbasis Daya Saing Organisasi dalam menyongsong MEA 2015. SEMINAR NASIONAL "Revolusi Mental Dan Kemandirian Bangsa Melalui Pendidikan Ilmu-Ilmu Sosial Dalam Menghadapi MEA 2015” Himpunan Sarjana Pendidikan Ilmu-Ilmu Sosial Indonesia, 1, 186-190.

Salam, R., Rosdiana, Suarlin, \& Akib, H. (2014). The Impact Of Policy on Region Expansion to Office Administrative Services in Barombong Subdistrict of Gowa District. International Conference on Mathematics, Sciences, Technology, Education and Their Applications, 1(1), 505 .

Shah, N., Irani, Z., \& Sharif, A. M. (2017). Big data in an HR context: Exploring organizational change readiness, employee attitudes and behaviors. Journal of Business Research, 70, 366-378. https://doi.org/https://doi.org/10.1016/j.jbusres.2016.08.010

Simon, Y., Mas' ud, M., \& Su'un, M. (2016). The role of apparatus competence, internal control system on good governance and the quality of financial statement information. Researchers World, 7(4), 123.

Thoha, M. (2003). Perilaku Birokrasi dalam Pelayanan Publik. Jakarta: Pustaka Pelajar.

Vianti, P. O., \& Netra, I. G. S. K. (2013). Pengaruh Gaya Kepemimpinan, Promosi Jabatan, dan Kompensasi Finansial Terhadap Kinerja Karyawan Pada PT. Grand Mega Bali Resort \& Spa Kuta, Bali. E-Jurnal Manajemen, 3(9). 
334 Jurnal Ilmiah Ilmu Administrasi Publik: Jurnal Pemikiran dan Penelitian Administrasi Publik Volume 9 Number 2, July- December 2019. Page 326-334 